\title{
Pengaruh Praktek Pengelolaan Sumber Daya Manusia dan Motivasi Kerja terhadap Kinerja Koperasi Melalui Partisipasi Anggota di KoperasiSetia Budi Wanita Malang
}

\author{
Choirul Insyiah ${ }^{1}$, Harianto Respati $^{2}$, Sunardi $^{3}$ \\ ${ }^{123}$ Universitas Merdeka Malang \\ Email : choirul_insyiah@yahoo.co.id
}

\begin{abstract}
This research was conducted to reveal the effect of human resource management and work motivation on member participation that has an impact on cooperative performance. This research design is quantitative research. The type of data used comes from the answers of respondents as many as 75 cooperative members. The data analysis technique used descriptive analysis (Mean) and Structural Equation Model which was completed with the SPSS program. The results of this study prove that human resource management and work motivation significantly influence member participation. Human resource management and work motivation have a significant effect on cooperative performance. Member participation has a significant effect on cooperative performance. This means that member participation is the key to success in efforts to improve cooperative performance related to the implementation of human resource management and work motivation of cooperative members.
\end{abstract}

Keywords: Human Resource Management, Motivation, Member Participation, Cooperative Performance.

Abstrak

Penelitian ini dilakukan untuk mengungkapkan pengaruh pengelolaan sumberdaya manusia dan motivasi kerja terhadap partisipasi anggota yang berdampak kepada kinerja koperasi. Desain Penelitian ini adalah penelitian kuantitatif. Jenis data yang digunakan berasal dari jawaban responden sebanyak 75 anggota koperasi. Teknik analisis data menggunakan analisis deskriptif (Mean) dan Struktural Equation Model yang diselesaiakan dengan program SPSS. Hasil penelitian ini membuktikan bahwa pengelolaan sumber daya manusia dan motivasi kerja berpengaruh signifikan terhadap partisipasi anggota. Pengelolaan sumber daya manusia dan motivasi kerja berpengaruh signifikan terhadapkinerja koperasi. Partisipasi anggota berpengaruh signifikan terhadap kinerja koperasi. Artinya partisipasi anggota menjadi kunci keberhasilan dalam upaya meningkatkan kinerja koperasi terkait dengan implementasi tatakelola sumberdaya manusia dan motivasi kerja anggota koperasi

Kata Kunci : Pengelolaan Sumber Daya Manusia, Motivasi, Partispasi Anggota, Kinerja Koperasi

(C) 2021 Jurnal Riset Inspirasi Manajemen dan Kewirausahaan

\section{PENDAHULUAN}

Sumber daya manusia memerlukan pengelolaan yang efektif agar dapat menciptakan kompetensi bagi perusahaan. Pengelolaan SDM saat ini dituntut untuk lebih proaktif dan responsif. Pengembangan pengelolaan SDM harus memenuhi kebutuhan organisasi dan tuntutan perkembangan. Kinerja organisasi termasuk di dalam koperasi merupakan hal penting sebagai hasil akhir dari semua aktivitas yang dipengaruhi oleh sumber daya manusia. Pengelolaan sumber daya manusia, baik secara langsung maupun tidak langsung berkaitan erat dengan motivasi. Pengelolaan organisasi koperasi, yang secara idiologi adalah milik anggota. Lembaga ini akan berjalan sesuai tujuan yang diinginkan, tidak lepas dari motivasi baik anggota maupun pengurusnya. Seperti yang disampaikan Martoyo (2000:165), bahwa motivasi adalah dorongan untuk melakukan pekerjaan dengan semangat bagi para pengurus koperasi. Di dalam koperasi diperlukan suatu motivasi yang dapat menimbulkan perilaku yang positif baik pengurus maupun anggotanya. Partisipasi anggota dalam koperasi, berperanan penting untuk mecapai kinerja sesuai yang diharapkan. Karena merupakan jembatan penghubung antara pengelolaan sumber daya manusia dengan motivasi kerja, baik anggota dan pengurus. Tanpa ada partisipasi aktif dari anggota mustahil kinerja koperasi dapat tercapai sesuai harapan. 
Hal unik yang terjadi di Koperasi SBW Malang ini adalah besarnya partisipasi anggota. Didalam pengelolaam sumber daya manusia dan motivasi bisa mengangkat partisipasi anggota, serta menghasilkan kinerja koperasi dengan baik.

Untuk itulah, Peneliti ingin membahas tentang variabel variabel yang digunakan untuk melakukan analisis korelasi penempatan kerja. Sehingga melalui kesesuaian penempatan kerja tersebut, koperasi bisa meningkatkan prestasi karyawan secara langsung dan juga berdampak pada meningkatnnya pelayanan koperasi. Berangkat dari uraian diatas, maka peneliti melakukan penelitian dengan judul "pengelolaan sumber daya manusia dan motivasi kerja terhadap partisipasi anggota yang berdampak terhadap kinerja Koperasi SBW Malang”.

\section{KAJIAN LITERATUR}

\section{Pengelolaan Sumber Daya Manusia}

Sumber daya manusia merupakan faktor yang penting dalam suatu organisasi. Sesuai dengan kodratnya, individu yang merupakan makhluk sosial dan memiliki keterbatasan kemampuan, tenaga maupun waktu, yang tidak bisa memenuhi kebutuhan serta keinginannya sendiri. Maka setiap individu akan melakukan kerjasama agar kebutuhan dan keinginannya tersebut dapat terpenuhi. Dalam hal ini mereka dapat bekerja sama dengan orang lain melalui organisasi untuk mencapai tujuan.

Keberadaan individu dalam organisasi mempunyai kedudukan penting, demikian juga dengan individu yang menjadi anggota koperasi. Melalui kemampuan yang dimilikinya, anggota koperasi dapat bekerja sama dan beraktifitas untuk dapat mewujudkan tujuan organisasi. Koperasi yang didirikan oleh sekelompok orang pada hakikatnya mempunyai tujuan yang sama, yaitu kesejahteraan semua anggotanya. Untuk dapat mencapai tujuan tersebut, koperasi akan berusaha untuk mengoptimalkan sumber daya yang ada, khususnya sumber daya manusia.

Fungsi manajemen pada Koperasi dilakukan oleh pengurus koperasi mulai dari perencanaan, pengorganisasian, pelaksanaan, sampai dengan pengawasan. Hal ini digunakan untuk mengelola sumber daya manusia, keuangan, permodalan, maupun pelayanan kepada anggota. Indikator keberhasilan manajemen sumber daya manusia di koperasi dapat dilihat dari 4 aspek kriteria penilaian. Yaitu aspek organisasi, aspek tata laksana dan manajemen, aspek produktivitas, serta aspek manfaat dan dampak (Dinas Koperasi Propinsi dan UMKM Jawa Timur, 2009).

\section{Motivasi Kerja}

melaksanakan suatu aktivitas dalam meraih tujuan apa yang direncanakan. Motivasi kerja juga dikenal sebagai arah perilaku seseorang dalam mewujudkan sesuatu yang diinginkan. Mangkunegara (2005 :16) menyatakan: motivasi terbentuk dari sikap (attitude) dalam menghadapi situasi kerja di suatu perusahaan (situation). Selanjutnya Robbins dan Judge (2008 :222) menyatakan bahwa motivasi kerja merupakan langkah-langkah untuk menjabarkan bahwa kesungguhan serta kegigihan dalam melakukan usaha akan menghasilkan suatu tujuan yang diharapkan. Mc. Donald (1959) "motivation is a energy change within the person characterized by affective arousel and anticipatory goal reactions" yang berarti motivasi kerja merupakan suatu semngat yang ada pada personal yang ditunjukkan dengan reaksi dan efektif untuk mencapai tujuan.

Ratuman, (2004:85) menjelaskan "fungsi motivasi yang mengakibatkan individu untuk menggerakan perilaku yang dapat melakukan perubahan emosional, fisik dan perubahan psikologis seseorang". Uno (2012 :64) mengatakan bahwa fungsi motivasi bagi manusia, ialah sebagai berikut : motivasi berperan sebagai alat penggerak yang dilakukan oleh manusia guna menentukan arah perbuatan, mencegah penyelewengan untuk mencapai tujuan. Dalam hal ini makin jelas pula jalan yang harus dilakukaan, mengevaluasi diri atas tindakan, artinya mampu menentukan tindakan mana yang harus dilakukan dengan serasi guna memperoleh tujuan dengan meninggalkan tindakan yang tidak bermanfaat bagi pencapaian tujuan.

Hamalik (2009 :175) menjelaskan fungsi motivasi antara lain: mendorong timbulnya perilaku atau suatu perbuatan, karena tanpa diikuti dengan motivasi atau dorongan tidak akan timbul perbuatan seperti belajar, kerja, dan lain-lain. Hal ini akan terjadi apabila seseorang tersebut memiliki motivasi, sebagai pengarah, artinya dapat menjadi jalan agar mampu menuju arah yang ingin di capai, sebagai penggerak. Swasto (2011:100) mengemukakan motivasi merupakan psikologis individual yang timbul dikarenakan ada suatu tekanan dalam melaksanakan dan memenuhi kebutuhan.

Teori motivasi mengacu pada Teori Dua faktor yang dikemukan oleh Frederick Herzberg dengan asumsi bahwa ada keterkaitan antara orang dengan jenis pekerjaan, ini merupakan hal yang sangat mendasar, perilaku individu terhadap pekerjaan akan dapat menentukan keberhasilan atau kegagalan. Wukir (2013:121) menjelaskan bahwa motivasi kerja terbagi menjadi dua kategori yaitu faktor motivation dan faktor hygiene. Faktor 
motivation yang mendorong prestasi yang bersifat intrinsik berasal atau bersumber dari dalam diri seseorang, sedangkan faktor hygiene atau pemeliharaan adalah gambaran kebutuhan fisiologis individu yang diharapkan untuk dipenuhi, antara lain meliputi gaji, jaminan kerja, hubungan antar pribadi, kebijaksanaan perusahaan. Faktor hygiene sangat diperlukan untuk menghindari ketidak puasan, faktor hygiene adalah gambaran yang menguntai sifat ekstrinsik yakni berasal dari luar yang turut menentukan perilaku seseorang.

Dari pendapat para ahli di atas, maka dapat disimpulkan bahwa motivasi merupakan respon personal terhadap sejumlah pernyataan mengenai keseluruhan usaha yang timbul dari dalam diri personal, agar tumbuh dorongan untuk menggerakkan perilaku seseorang guna mencapai tujuan tertentu.

\section{Partisipasi Anggota Koperasi}

Partisipasi anggota, merupakan keterlibatan anggota sesuai dengan tugas dan tanggung jawab dalam koperasi. Partisipasi berkaitan dengan hak dan kewajiban seorang anggota yang menjamin badan usaha koperasi dapat berjalan sesuai yang diharapkan. Hal ini menjadi ukuran dasar dan merupakan kekuatan untuk meningkatkan kinerja usaha koperasi. Hanel (2002:66) menyatakan pertisipasi anggota dapat bertahan menjadi lebih baik, bila terjadi keselarasan anggota dengan program, yang diserasikan dengan kemampuan wirausaha, sesuai keputusan rapat anggota.

Sebagaimana Ropke (2003 : 68) menyatakan, bahwa untuk mengatasi kinerja koperasi yang buruk diperlukan partisipasi anggota, guna mencegah penyalah gunaan dan membuat pengurus atau manajemen koperasi lebih bertanggung jawab. Untuk memaksimalkan peran anggota inilah, koperasi memberikan balas jasa berdasarkan simpanan dan partisipasi anggota pada koperasi dan memberikan fasilitas pelayanan ekstra yang lebih baik. Pengertian anggota koperasi menurut para ahli, adalah seseorang yang telah tercatat pada buku daftar anggota, melunasi simpanan pokok dan simpanan wajib, berperan sebagai pemilik sekaligus pengguna jasa dalam kegiatan yang ada di koperasi.

Kedudukan anggota di dalam badan usaha koperasi memiliki peranan yang sangat penting. Karena selain menjadi pemilik, sekaligus menjadi pelanggan dari badan usaha milik koperasi itu sendiri.

Peran penting inilah, menunjukkan bahwa partisipasi anggota menjadi faktor penentu dalam menunjang kinerja koperasi. Hendar (2005:93) menyatakan bahwa, partisipasi anggota koperasi di pandang dari segi kepentingan dapat dibagi menjadi partisipasi langsung dan partisipasi tidak langsung dapat dilaksanakan secara bersama-sama tergantung pada situasi dan kondisi serta aturan yang berlaku.

Partisipasi yang bersifat kontributif, adalah peran anggota sebagai pemodal koperasi. Anggota koperasi mampu memberikan suatu dukungan terhadap keberadaan serta perkembangaan koperasi baik keuangan dan kelembagaan, seperti kontribusi keuangan, meliputi simpanan. Partisipasi yang bersifat insentif, adalah penggunaan kegiatan operasional koperasi sesaui dengan aturan yang dituangkan dan diputuskan dalam rapat anggota.

\section{Kinerja}

Kinerja organisasi menurut Sinambela (2012 : 186) didefenisikan sebagai organisasi efektivitas untuk memenuhi kebutuhan dari setiap kelompok melalui usaha yang telah ditetapkan untuk meningkatkan kemampuan organisasi secara berkelanjutan. Faktor-faktor yang mempengaruhi kinerja adalah pegawai dan pekerjaan yang dilakukannya. Mahmudi (2010 : 21).) Penilaian keberhasilan suatu pekerjaan atau performance appraisal merupakan alur dari evaluasi kinerja yang seharusnya dilakukan didalam organisasi. Martoyo (2000:92). Penilaian pertasi kerja yang dilaksanakan sesuai mekanisme yang ada akan berdampak positif bagi organisasi. Penilaian kinerja koperasi adalah media yang tepat dan bermanfaat untuk melihat, mengevaluasi dan memotivasi anggota terhadap pertumbuhan dan pengembangan koperasi. Bernardi dan Russel (Gomes, 1993 :379) mengajukan enam kriteria yang dipergunakan untuk menilai kinerja suatu organisasi yaitu quality, quantity, timeline, costeffectiveness, need for supervisor, dan interpersonal Impac.

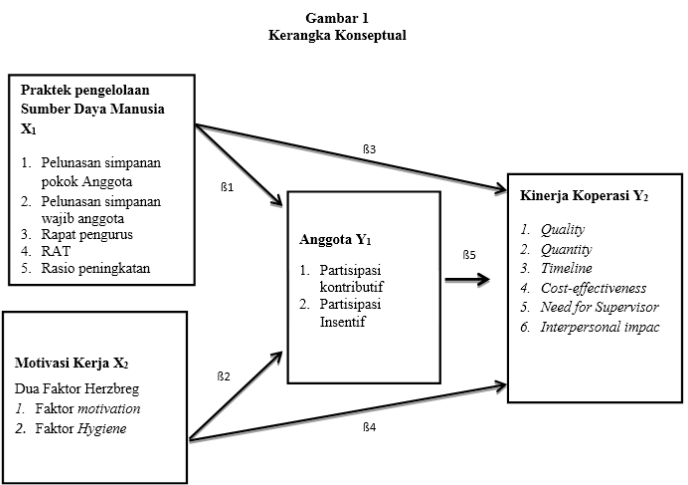

\section{Hipotesis Penelitian}

Berdasarkan permasalahan yang sudah dirumuskan, maka hipotesis penelitian yang akan diuji adalah : 
1. Praktik Pengelolaan sumber daya manusia dan motivasi kerja berpengaruh positif dan signifikan terhadap partisipasi anggota.

2. Partisipasi anggota berpengaruh positif dan signifikan terhadap kinerja organisasi di Koperasi Setia Budi Wanita Malang.

3. Praktik pengelolaan sumber daya manusia dan motivasi kerja berpengaruh positif dan signifikan terhadap kinerja organisasi melalui partisipasi anggota.

\section{METODE PENELITIAN}

\section{Rancangan Penelitian}

Penelitian ini menganalisis hubungan berdasarkan masalah yang ada. Tujuannya untuk mengetahui pengaruh langsung antara variabel praktek pengelolaan sumber daya manusia, motivasi kerja terhadap kinerja Koperasi. Dan pengaruh tidak langsung variabel praktek pengelolaan sumberdaya manusia, motivasi kerja, yang dimediasi oleh partisipasi anggota terhadap kinerja koperasi.

Penelitian ini termasuk penelitian eksplanagtori untuk menguji hipotesis (hypothesis testing). Penelitian ini termasuk penelitian kuantitatif dan dalam pengumpulan data menggunakan pendekatan persepsional sebagai pengukurannya. Ruang lingkupnya meliputi bidang manajemen yang fokus pada kinerja organisasi yang dipengaruhi oleh sumber daya manusia dan motivasi kerja melalui partisipasi anggota.

Lokasi penelitian adalah Koperasi Setia Budi Wanita, alamat di jalan Raden Intan Kav. 108 Arjosari, Blimbing, Kota Malang Jawa Timur. Variabel penelitian terdiri dari :

1) variabel eksogen merupakan variabel penyebab yang meliputi Pengelolaan Sumber Daya Manusia (X1) dan Motivasi Kerja (X2),

2) variabel endogen merupakan variabel yang dipengaruhi meliputi partisipasi anggota (Y1) sebagai variabel intervening dan kinerja organisasi (Y2).

Jenis data yang digunakan dalam penelitian adalah jenis data kuantitatif yang berasal dari data kualitatif (dengan menyebarkan angket ke responden) yang dikuantitatifkan agar dapat diproses menggunakan statistik.

Data primer yang diperoleh langsung dari lapangan, bersumber dari responden yang merupakan anggota Koperasi Setia Budi Wanita Malang Jawa Timur, berupa pernyataan tentang variabel Praktek pengelolaan sumber daya manusia , motivasi kerja terhadap kinerja koperasi melalui pasrtisipasi anggota. Data sekunder, diperoleh dari dokumentasi, buku-buku referensi, dan informasi yang berhubungan dengan penelitian ini.

Populasi dimaksud adalah anggota Koperasi Setia Budi Wanita Malang Jawa Timur. Secara keseluruhan berjumlah 9.300 orang dan terbagi lagi ke dalam 300 kelompok, maka populasi penelitian ini adalah 300 unit kelompok.

Sampel yang diambil sebanyak 75 orang, dengan teknik pengambilan acak sederhana (sampel random sampling). Data primer berupa kuesioner, berisi pernyataan yang bersifat tertutup yang disusun berdasarkan hasil penelitian, kajian teoritis, dan pengalaman peneliti. Analisis data meliputi deskiptif menggunakan alat statistik Mean dan Modus untuk menjelaskan persepsi responden. Analisis data melalui model Persamaan Struktural (Structural Equation Modelling) yang merupakan gabungan dari analisis faktor, regresi dan analisis jalur (path analysis).

Analisis jalur dimaksudkan untuk mengetahui pengaruh langsung antara variabel Praktek Pengelolaan Sumber Daya Manusia dan motivasi kerja terhadap kinerja koperasi Setia Budi Wanita Malang. Dan pengaruh tidak langsung variabel Praktek pengelolaan sumber daya manusia dan motivasi kerja terhadap kinerja koperasi melalui partisipasi anggota sebagai variabel intervening.

\section{HASIL PENELITIAN DAN PEMBAHASAN}

\section{Analisa Hasil Penelitian}

Peneliti menyajikan deskripsi variabel penelitian dengan mengambil kisi-kisi dan indikator yang paling dominan dari setiap variabel sebagaimana tabel berikut ini :

Tabel 1

Ringkasan Distribusi Frekuensi Variabel, indikator, dan kisi-kisi indikator yang paling dominan

\begin{tabular}{|c|c|c|}
\hline Variabel & Indikator & Kisi-kisi indikator \\
\hline $\begin{array}{l}\text { Pengelolaan } \\
\text { SDM }(X 1) \text {, rata- } \\
\text { rata skor } 4,13\end{array}$ & $\begin{array}{l}\text { Pelunasan Simpanan } \\
\text { Wajib, skor } 4,37\end{array}$ & $\begin{array}{l}\text { Pelunasan Simpanan } \\
\text { Wajib mampu } \\
\text { meningkatkan kualitas } \\
\text { dan kuantitas kinerja } \\
\text { koperasi dalam melayani } \\
\text { kebutuhan anggota, skor } \\
4,22\end{array}$ \\
\hline $\begin{array}{l}\text { Motivasi Kerja } \\
(\mathrm{X} 2) \text {, rata-rata } \\
\text { skor } 4,25\end{array}$ & $\begin{array}{l}\text { Teori Motivasi, skor } \\
4,20\end{array}$ & $\begin{array}{l}\text { Anggota memahami } \\
\text { penuh atas apa yang } \\
\text { telah menjadi kewajiban, } \\
\text { skor } 4,47\end{array}$ \\
\hline $\begin{array}{l}\text { Partisipasi } \\
\text { Anggota (Y1), } \\
\text { rata-rata skor 4,57 }\end{array}$ & $\begin{array}{l}\text { Partisipasi } \\
\text { Kontributif, skor } \\
4,60\end{array}$ & $\begin{array}{l}\text { Anggota membayar } \\
\text { Simpanan Pokok dan } \\
\text { Simpanan Wajib, skor } \\
4,84\end{array}$ \\
\hline $\begin{array}{l}\text { Kinerja Koperasi } \\
\text { (Y2), rata-rata } \\
\text { skor } 4,83\end{array}$ & Kualitas, skor 4,49 & $\begin{array}{l}\text { Anggota mendapat } \\
\text { pelatihan koperasi, skor } \\
4,71\end{array}$ \\
\hline
\end{tabular}

Sumber: Data primer diolah, 2019 
Berdasarkan tabel 2 diatas diperoleh bahwa rata-rata skor untuk data pengelolaan sumber daya manusia (X1) adalah sebesar 4,13 dengan penekanan pada pelunasan simpanan wajib dengan rata-rata skor 4,37. Hal ini menunjukkan bahwa responden cenderung setuju bahwa penekanan pada pelunasan simpanan wajib merupakan indikator yang paling mempengaruhi pengelolaan sumber daya manusia.

Sebaran jawaban responden secara keseluruhan tentang variabel motivasi kerja adalah 4,25. Hal ini menunjukkan bahwa responden cenderung setuju bahwa motivasi kerja ditentukan oleh teori motivasi dan teori hygine. Jawaban responden tentang teori motivasi dominan dengan skor 4,20. Kisi-kisi indikatornya adalah Anggota memahami penuh atas apa yang telah menjadi kewajiban, dengan rata-rata skor tertinggi yaitu sebesar 4,47 yang menunjukkan bahwa motivasi kerja sangat dipengaruhi oleh adanya pemahaman tentang kewajiban sebagai anggota koperasi SBW Malang.

Sebaran jawaban responden secara keseluruhan rata-rata variabel partisipasi anggota adalah sebesar 4,57. Hal ini menunjukkan bahwa responden cenderung sangat setuju bahwa partisipasi anggota ditentukan oleh partisipasi kontributif dan partipasi insentif. Hal utama yang dapat dilihat adalah partisipasi kontributit anggota yang tercermin dari angka rata-rata skor sebesar 4,60. Dalam hal ini anggota berkontribusi dengan membayar simpanan pokok, simpanan wajib, dan aktif dalam memberi saran-saran perbaikan untuk koperasi.

Secara keseluruhan rata-rata variabel kinerja koperasi sebesar 4,83 hal ini menggambarkan bahwa responden cenderung sangat setuju bahwa kinerja koperasi dipengaruhi oleh quality, quantity, cost effectiveness, need for supervisor dan interpersonal impact. Hal yang paling mempengaruhi kinerja koperasi adalah indikator quality yang dibuktikan rata-rata skor sebesar 4,49. Di sini anggota setuju bahwa selain pengurus, anggota mendapatkan pelatihan tentang koperasi dan senantiasa mendukung laporan perkembangan koperasi yang selalu meningkat.

\section{Analisa Jalur}

Berdasarkan pengolahan data statistik, maka didapatkan perhitungan analisis jalur seperti di dalam tabel berikut :
Tabel 2

Ringkasan Hasil Analisis Jalur

\begin{tabular}{|c|c|c|c|}
\hline Variabel & $\begin{array}{l}\text { Pengaruh } \\
\text { Langsung }\end{array}$ & $\begin{array}{c}\text { Pengaruh } \\
\text { Tidak } \\
\text { Langsung }\end{array}$ & $\begin{array}{c}\text { Pengaruh } \\
\text { Total }\end{array}$ \\
\hline Pengelolaan Sumber Daya Manusia $\rightarrow$ Kinerja Koperasi & 0,461 & & 0,461 \\
\hline Pengelolaan Sumber Daya Manusia $\rightarrow$ Partispasi Anggota & 0.272 & & 0,272 \\
\hline Motivasi Kerja $\rightarrow$ Partisipasi Anggota & 0,372 & & 0,372 \\
\hline Partisipasi Anggota $\rightarrow$ Kineja Koperasi & 0,575 & & 0,575 \\
\hline Motiasi $\rightarrow$ Kinerja Koperasi & 0,301 & & 0,301 \\
\hline $\begin{array}{l}\text { Pengelolaan Sumber Daya Manusia } \rightarrow \text { Partisipasi Anggota } \rightarrow \\
\text { Kinerja Koperasi }\end{array}$ & & $\begin{array}{l}0,272 \times 0,575 \\
=0,156\end{array}$ & 0,617 \\
\hline Motivasi Kerja $\rightarrow$ Partisipasi Anggota $\rightarrow$ Kineja Koperasi & & $\begin{array}{l}0,372 \times 0,575 \\
=0,213\end{array}$ & 0,514 \\
\hline
\end{tabular}

* signifikan $\alpha 5 \%$

Tabel 3 menunjukkan bahwa pengaruh total praktik pengelolaan sumber daya manusia terhadap kinerja koperasi melalui partisipasi anggota sebesar 0,617. Angka ini lebih besar dari pada pengaruh total motivasi terhadap kinerja koperasi melalui partisipasi anggota (0,514). Pengaruh langsung praktik pengelolaan sumber daya manusia terhadap kinerja sebesar 0,461, angka ini lebih besar daripada pengaruh motivasi terhadap kinerja koperasi melalui partisipasi anggota $(0,213)$. Dengan demikian jalur yang paling kuat pada model persamaan struktural yang dibangun (Gambar 1) terletak pada jalur pengaruh langsung praktik pengeloaan sumber daya manusia terhadap kinerja koperasi.

Gambar 1

Hasil Analisis Jalur

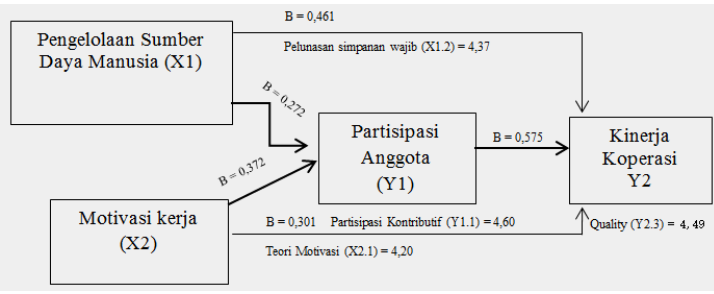

Sumber: Data primer diolah, 2019

\section{Pengujian Hipotesis}

Uji Hipotesis 1

Hasil regresi 1 menguji hipotesis 1 ditampilkan pada Tabel di bawah ini:

Tabel 3

Pengaruh Pengelolaan Sumber Daya Manusia dan Motivasi terhadap Partisipasi Anggota

\begin{tabular}{lccc}
\hline \multicolumn{1}{c}{ Variabel } & $\begin{array}{c}\text { Koefisien } \\
\text { regresi }\end{array}$ & Nilai t & Nilai p \\
\hline $\begin{array}{l}\text { Pengelolaan Sumber } \\
\text { Daya Manusia } \rightarrow\end{array}$ & 0,272 & 2,289 & 0,025 \\
$\begin{array}{l}\text { Partisipasi Anggota } \\
\text { Motivasi } \rightarrow \text { Partisipasi } \\
\text { Anggota }\end{array}$ & 0,372 & 3,122 & 0,003 \\
\hline $\mathrm{R}$
\end{tabular}

$\mathrm{R}=0,575$

R Square $\left(R^{2}\right)=0,331$

Sumber: Data primer diolah, 2019 
https://ejurnal.stimi-bjm.ac.id/index.php/JRIMK

Pada tabel 4 diperoleh nilai koefisien beta pengelolaan sumber daya manusia sebesar 0,272 dan nilai t sebesar 2,289 dan nilai p sebesar 0,0205 lebih kecil dari $\mathrm{p} \leq 0,05 \quad(\alpha=5 \%)$, yang berarti bahwa pengelolaan sumber daya manusia berpengaruh signifikan terhadap partisipasi anggota. Nilai koefisien motivasi adalah sebesar 0,372 dan nilai $t$ sebesar 3,122 dan nilai $p$ sebesar 0,003 lebih kecil dari $\mathrm{p} \leq 0,05(\alpha=5 \%)$, bahwa pengelolaan sumber daya manusia berpengaruh signifikan terhadap partisipasi anggota. Pengelolaan sumber daya manusia (X1) dan motivasi (X2) memberikan pengaruh terhadap partisipasi anggota (Y1), atau $\mathrm{X} 1+\mathrm{X} 2=\mathrm{Y} 1$. Kesimpulannya, hipotesis pertama yang menyatakan bahwa terdapat pengaruh antara pengelolaan sumber daya manusia dan motivasi terhadap partisipasi anggota Koperasi Setia Budi Wanita Malang Jawa Timur teruji.

Uji Hipotesis 2

Tabel 4

Pengaruh Partisipasi Anggota terhadap Kinerja Koperasi

\begin{tabular}{lccc}
\hline \multicolumn{1}{c}{ Variabel } & $\begin{array}{c}\text { Koefisien } \\
\text { regresi }\end{array}$ & Nilai t & Nilai p \\
\hline $\begin{array}{l}\text { Partisipasi anggota } \rightarrow \\
\text { Kinerja Koperasi }\end{array}$ & 0,575 & 6,012 & 0,000 \\
\hline $\begin{array}{l}\mathrm{R}=0,575 \\
\mathrm{R} \text { Square }\left(\mathrm{R}^{2}\right)=0,331\end{array}$ & & & \\
\hline
\end{tabular}

Sumber : Data primer diolah, 2019

Berdasarkan tabel 4 diperoleh nilai koefesien beta partisipasi anggota sebesar 0,575 dan nilai $t$ sebesar 6,012 dan nilai $\mathrm{p}$ sebesar 0,000 lebih kecildari $\mathrm{p}=0,05(\square=5 \%)$, yang berarti bahwa partisipasi anggota berpengaruh signifikan terhadap kinerja koperasi, sehingga hipotesis ketiga yang menyatakan bahwa partisipasi anggota berpengaruh positif dan signifikan terhadap kinerja koperasisecara statistik teruji.

\section{Uji Hipotesis 3}

Tabel 5

Pengaruh Praktik pengelolaan sumber daya manusa dan motivasi kerja terhadap kinerja koperasi melalui partisipasi anggota

\begin{tabular}{|c|c|c|c|}
\hline Variabel & $\begin{array}{c}\text { Koefisien } \\
\text { regresi }\end{array}$ & Nilai t & Nilai p \\
\hline $\begin{array}{l}\text { Pengelolaan } \\
\text { Sumber Daya } \\
\text { Manusia } \rightarrow \\
\text { Kinerja } \\
\text { Koperasi }\end{array}$ & 0,461 & 4.339 & 0,000 \\
\hline $\begin{array}{l}\text { Pengelolaan } \\
\text { Sumber Daya }\end{array}$ & 0,272 & 2,289 & 0,025 \\
\hline
\end{tabular}

\begin{tabular}{lccc}
\hline \multicolumn{1}{c}{ Variabel } & $\begin{array}{c}\text { Koefisien } \\
\text { regresi }\end{array}$ & Nilai t & Nilai p \\
\hline $\begin{array}{l}\text { Manusia } \rightarrow \\
\text { Partispasi } \\
\text { Anggota }\end{array}$ & & & \\
\hline $\begin{array}{l}\text { Motivasi Kerja } \\
\rightarrow \text { Partisipasi }\end{array}$ & 0,372 & 3,122 & 0,003 \\
Anggota & & & \\
\hline $\begin{array}{l}\text { Partisipasi } \\
\text { Anggota } \rightarrow\end{array}$ & 0,575 & 6,012 & 0,000 \\
Kinerja \\
Koperasi
\end{tabular}

Sumber: Data diolah primer, 2019

Analisis Tabel 5 menunjukkan bahwa partisipasi anggota berstatus sebagai variabel intervening yang dapat memediasi variabel praktik pengelolaan sumber daya manusia, karena nilai koefesien b1, b4 dan b5 memiliki nilai probabilitas kurang dari $5 \%$. Partisipasi anggota berstatus sebagai variabel intervening yang dapat memediasi variabel motivasi kerja terhadap kinerja koperasi, karena nilai pengaruh total $(0,514)$ lebih besar dari pengaruh langsung (0,301). Dengan demikiran hipotesis keempat yang menyatakan praktek pengelolaan sumber daya manusia dan motivasi kerja positif dan signifikan terhadap kinerja koperasi melalui partisipasi anggota secara statistik teruji.

\section{Pembahasan}

1. Deskripsi Pengelolaan Sumber Daya Manusia, Motivasi, Partisipasi Anggota, dan Kinerja Koperasi.

Pengelolaan sumber daya manusia ditentukan oleh pelunasan simpanan pokok Anggota, pelunasan simpanan wajib anggota, rapat pengurus, RAT, dan rasio peningkatan jumlah anggota. Kontribusi yang paling utama pada praktik pengelolaan sumber daya manusia adalah pelunasan simpanan wajib, dengan nilai rata- rata sebesar 4, 37. Ini karena simpanan wajib merupakan simpanan yang harus dilunasi oleh anggota setiap bulan. Berdasarkan pada kriteria pelunasan simpanan wajib, menunjukkan bahwa mayoritas anggota koperasi setia budi wanita Malang (80 \%) telah memenuhi kewajibannya.

Hal ini berarti, bahwa sumber daya manusia di koperasi setia budi wanita Malang, telah sadar akan kewajibannya sebagai anggota koperasi yaitu membayar atau melunasi simpanan wajib. Dengan 
demikian koperasi setia Budi wanita Malang semakin besar. Hal ini sejalan dengan penelitian yang telah dilakukan oleh Ratnawati (2015) yang menyatakan bahwa pelunasan simpanan wajib merupakan modal utama yang besar bagi sebuah koperasi wanita.

Motivasi kerja pada koperasi Setia Budi Wanita Malang terdiri atas dua indikator yakni faktor motivation dan faktor hygine. Faktor motivation diutamakan pada pemahaman anggota dan pengurus terhadap tugas, kewajiban dan tanggung jawab terhadap koperasi. Ini dibuktikan dengan nilai rata-rata sebesar 4,47 bahwa anggota memahami penuh atas apa yang telah menjadi kewajibannya. Sedangkan faktor hygine anggota terdorong untuk mengembangkan diri dengan menciptakan kreativitas baru dalam meningkatkan sumber daya manusia untuk perkembangan dan kinerja koperasi. Motivasi kerja merupakan suatu dorongan atau kekuatan untuk melakukan pekerjaan dan kewajiban dalam mengembangkan koperasi melalui partisipasi. Hasil penelitian ini mendukung penelitian yang telah dilakukan oleh Muryani (2018) yang menyatakan bahwa motivasi merupakan satu dorongan yang kuat untuk berpartisipasi.

Partisipasi anggota merupakan keterlibatan anggota terhadap tanggung jawab dalam menyelenggarakan kegiatan koperasi. Ada dua partisipasi pada koperasi yaitu partisipasi kontributif dan partisipasi insentif. Partisipasi kontributif mengutamakan pada keaktifan anggota dan pengurus dalam membayar simpanan pokok sebagai anggota baru, simpanan wajib, simpanan sukarela yang dilakukan setiap bulan dengan jadwal yang telah ditentukan. Ini dapat dibuktikan dengan nilai rata-rata skor pasrtisipasi anggota sebasar 4,84. Dan keaktifan anggota dalam memberi saran saat rapat baik rapat anggota maupun rapat anggota tahunan yang dilaksanakan minimal satu kali dalam satu tahun sebesar 4,13.

Sedangkan partisipasi insentif mengutamakan pada keaktifan anggota untuk melakukan pinjaman dan merasa diuntungkan dengan adanya koperasi setia Budi Wanita Malang hal ini. Dengan partisipasi anggota ini sudah menunjukkan bahwa ada keterlibatan yang aktif dalam menyelenggarakan kegiatan berkoperasi dan menunjukkan bahwa kinerjanya sangat baik serta berkembang dengan pesat.

2. Pengaruh Pengelolaan Sumber Daya Manusia dan Motivasi terhadap Partisipasi Anggota

Pengelolaan sumber daya manusia berpengaruh terhadap partisipasi anggota dengan nilai koefesien sebesar 0,272. Karena dengan pengelolaan sumber daya manusia memotivasi pengurus dan anggota koperasi berpartisipasi untuk mengembangkan koperasi serta merasakan manfaat dan keuntungan dengan keberadaan koperasi Setia Budi Wanita Malang. Hasil penelitian ini mendukung penelitian terdahulu yang dilakukan oleh Ratnawati (2015), bahwa Koperasi Wanita didirikan dengan tujuan untuk mensejahterakan anggotanya dan memberdayakan kaum perempuan.

Tujuan ini berbeda dengan tujuan organisasi ekonomi lainnya yang mencari laba. Koperasi yang diteliti merupakan koperasi wanita, di mana anggotanya adalah kaum perempuan, baik sebagai ibu rumah tangga maupun yang bekerja. Pemberdayaan sumber daya manusia pada koperasi wanita sudah sangat baik dengan menggunakan aspek organisasi sebagai dasar untuk menilai kinerja koperasi.

Hasil penelitian ini juga telah membuktikan bahwa motivasi kerja berpengaruh terhadap variabel partisipasi anggota dengan indikator motivasi, yakni faktor motivation dan faktor hygine sehingga dapat meningkatkan partisipasi anggota koperasi setia budi wanita Malang. Penelitian ini mendukung penelitian yang telah dilakukan oleh Muryani (2018), bahwa motivasi sebagai dorongan atau kekuatan anggota dan pengurus untuk melakukan tanggung jawab dan kewajibannya.

\section{Pengaruh Partisipasi Anggota dan Motivasi Kerja terhadap Kinerja Koperasi}

Partisipasi kontributif dan partisipasi insentif anggota medorong pengurus untuk mengembangkan kinerja dan merasakan manfaat serta keuntungan dengan keberadaan koperasi setia budi wanita Malang. Penelitian ini mendukung penelitian yag telah dilakukan oleh Muryani (2018) partisipasi anggota koperasi dipandang dari segi kepentingannya dibagi menjadi dua jenis partisipasi yakni : Partisipasi kontributif, adalah peran anggota sebagai pemilik (pemodal), dan partisipasi insentif, adalah peran anggota sebagai pelanggan atau pengguna koperasi.

Sedangkan motivasi kerja menunjukkan pengaruh yang siginifikan terhadap kinerja koperasi, sehingga dapat mencapai keberhasilanya sesuai dengan apa yang diharapkan oleh pengurus dan anggota. Ini mendukung penelitian yang telah dilakukan oleh Uno (2012), bahwa motivasi kerja merupakan dorongan kekuatan yang ditimbulkan dari dalam atau luar diri seseorang untuk mencapai tujuan organiasi yang telah ditetapkan dan dikung penelitian Muryani (20018) ada pengaruh positif antar variabel motivasi dengan kinerja koperasi 
yakni bila motivasi ditingkatkan akan diikuti dengan penguatan kinerja koperasi.

\section{Pengaruh Partisipasi Anggota terhadap Kinerja Koperasi}

Partisipasi anggota berpengaruh signifikan terhadap kinerja koperasi yang berarti semakin tinggi partisipasi anggota maka dapat meningktakan kinerja koperasi. Indikator yang memberikan kontributif terbesar pada partipasi anggota adalah partisipasi kontributif secara keseluruhan. Rata-rata variabel partisipasi anggota adalah sebesar 4,57. Hal ini menunjukkan bahwa responden cenderung sangat setuju bahwa partisipasi anggota ditentukan oleh partisipasi kontributif dan partipasi insentif.

Ini dapat dilihat dari partisipasi kontributif anggota yang tercermin dari angka rata-rata skor yang besar, anggota berkontribusi dengan membayar simpanan pokok, simpanan wajib, dan aktif dalam memberi saran-saran perbaikan untuk koperasi. Selain itu responden juga sangat setuju bahwa partisipasi insentif anggota juga merupakan hal penting dari partisipasi anggota yang terlihat dengan rata-rata skor sebesar 4,53. Hal ini ditunjukkan anggota melalui kegiatan simpan pinjam dan anggota merasa diuntungkan dengan didirikannya koperasi.

\section{Pengaruh Praktik Pengelolaan Sumber} Daya Manusia dan Motivasi Kerja terhadap Kinerja Koperasi Melalui Partisipasi Anggota

Partisipasi Anggota memediasi pengaruh praktik pengelolaan sumber daya manusia dan motivasi kerja terhadap kinerja koperasi. Yang berarti bahwa semakin tinggi partisipasi anggota maka akan semakin baik kinerja koperasi. Partisipasi anggota menjadi salah satu kriteria evaluasi saat menilai kinerja koperasi, karena suatu organisasi koperasi tidak bisa lepas dari partisipasi anggota. Hasil penelitian ini mendukung penelitian terdahlu Muryani (2018), yang menyatakan bahwa partisipasi anggota mengandung potensi luar biasa untuk membina dan mengembangkan kinerja koperasi.

Partisipasi anggota mampu memediasi motivasi kerja terhadap kinerja koperasi, yang berarti bahwa kinerja koperasi dapat meningkat jika anggota memiliki motivasi yang kuat baik dari dalam maupun luar diri anggota itu sendiri. Motivasi menjadi sangat penting terhadap partisipasi anggota karena melalui keinginan atau motivasi mempengaruhi partisipasi anggota.

\section{Temuan Penelitian}

Partisipasi anggota merupakan media atau sarana dari praktik pengelolaan sumber daya manusia dan motivasi kerja untuk meningkatkan kinerja koperasi. Namun dalam penelitian ini variabel yang langsung memepengaruhi kinerja koperasi yakni dari pengelolaan sumber daya manusia memiliki kapasitas yang lebih besar dengan nilai koefesien 0,461.

Selain itu, variabel Sumberdaya Manusia memiliki pengaruh langsung terhadap Partisipasi Anggota dengan nilai koefisien yang cenderung lebih rendah dan signifikan sebesar 0.272. Sementara itu, dari variabel motivasi kerja memiliki kecendurungan yang signifikan untuk meningkatkan partisipasi anggota didalam mempengaruhi kinerja koperasi dengan nilai koefisisen sebesar 0,372. Sedangkan pengaruh langsung variabel motivasi terhadap kinerja koperasi memiliki nilai kofisien yang cenderung lebih rendah yaitu 0,301 dibanding dengan niali koefisien variabel motivasi terhadap kinerja koperasi melalui partisipasi anggota.

\section{PENUTUP}

\section{Kesimpulan}

Berdasarkan hasil penelitian dan pembahasan yang dilakukan maka dapat ditarik kesimpulan sebagai berikut :

1. Hasil statistik deskriptif menunjukkan bahwa praktik pengelolaan sumber daya manusia, motivasi kerja, partisipasi anggota dan kinerja koperasi sudah menunjukkan keterlibatan aktif dalam menyelenggarakan koperasi di Koperasi SBW Malang. Pengurus dan anggota dinilai baik dalam penyelenggaraan praktik pengelolaan sumber daya manusia koperasi, peran pengurus dinilai baik dalam menyelenggarakan pendidikan dan pelatihan yang diberikan terhadap anggota. Motivasi sebagai dorongan dan kekuatan pengurus dan anggota untuk melaksanakan hak dan kewajiban sudah sangat baik dalam pengembangan koperasi SB Wanita Malang, begitu juga dengan partisipasi anggota yang aktif dalam menyelenggarakan kegiatan. Kinerja koperasi secara umum sudah sangat memuaskan tidak hanya bagi para angggota karena Koperasi SBW Malang masuk dalam koperasi yang berprestasi dan koperasi terbaik Nasional.

2. Praktik pengelolaan sumber daya manusia dan motivasi kerja berpengaruh terhadap kinerja koperasi SBW Malang. Kontribusi praktik pengelolaan sumber daya manusia disamping memberikan pendidikan dan pelatihan lebih pada memberi motivasi dan semangat untuk bertanggung jawab terhadap pelunasan simpanan pokok dan simpanan wajib yang 
menjadi salah satu modal terbesar dalam koperasi.

3. Kinerja koperasi SBW Malang dipengaruhi oleh partispasi anggota yang terdiri dari partisipasi kontributif yang merupakan peran anggota sebagai pemilik atau yang memberikan modal koperasi dan partisipasi insentif anggota berperan sebagai pelanggan atau pengguna program dan fasilitas-fasilitas yang diberikan oleh koperasi.

4. Partisipasi anggota memediasi pengaruh praktik pengelolaan sumber daya manusia dan motivasi kerja terhadap kinerja koperasi SBW Malang. Hal ini menunjukkan bahwa partisipasi anggota menjadi aspek penting yang harus diperhatikan dalam meningkatkan kinerja koperasi, berupa pendidikan dan pelatihan dan memberikan pinjaman modal terhadap anggota yang didukung dengan semangat tinggi untuk menumbuhkan motivasi kerja yang berpengaruh secara signifikan terhadap kinerja koperasi SBW Malang.

\section{Saran}

Dari uraian-uraian di atas maka dapat diberikan saran-saran bahwa Koperasi SBW Malang tetap selalu mengutamakan kepentingan anggota dengan memperjuangkan kesejahteraan anggotanya. Selalu melakukan sosialisasi penggunaan sistem tanggung renteng dalam melaksanakan kewajiban, senantiasa membangun program yang dapat meningkatkan pemahaman sumber daya manusia koperasi dan dapat meningkatkan kinerja koperasi. Di samping itu hasil penelitian ini diharapkan menjadi dasar pijakan secara umum dalam dunia perkoperasian dan secara khusus untuk Koperasi SBW Malang Jawa Timur sebagai sumber untuk tujuan koperasi itu sendiri melalui model yang sudah dibangun berdasarkan aspek sumberdaya manusia dan motivasi dalam berkoperasi.

\section{DAFTAR PUSTAKA}

AA. Anwar Prabu Mangkunegara. (2013). Manajemen Sumber Daya Manusia Perusahaan, Remaja Rosdakarya, Bandung.

Abdullah, M. (2014). Manajemen dan Evaluasi Kinerja Karyawan. Yogyakarta : Aswaja Pressindo.

Arifin Sitio dan Tamba Halomoan. (2001).Koperasi : Teori dan Praktik.Jakarta : Erlangga

Arikunto, S. (2010). Prosedur Penelitian Suatu Pendekatan Praktik. Jakarta Rineka Cipta.
Anwar, M. A. (2016). Pengaruh Sumber Daya Internal, Budaya Organisasi dan Strategi Bersaing Terhadap Motivasi dan Kinerja Koperasi Simpan PinjamJombang. Malang : Desertasi Universitas Merdeka Malang.

Ahdiyana, M. (2014). Dimensi dalam Kinerja Organisasi. Jurnal Ilmu Sosial dan Ekonomi.

B.Uno, Hamzah.(2012).Teori Motivasi dan Pengukurannya. Jakarta: PT. Bumi. Aksara.

Bernadin, H. J., \& Russel, J. E. (1993). Human Resource Manajemen. New Jersey : International Editions Upper Saddler Rivers, Pretice Hall. p. 279.

Budi Harjo, A. (2011). Menuju Pencapaian Kinerja Optimim. Sintetis Toeri untuk Mengungkap “ Kotak Hitam" Organisasi. Jakarta : Prasetya Mulya Publishing.

Chaniago, A. (1993). Perkoperasian Bandung : Angkasa

Davis, Keith. (2010). Organizational Behavior Human Behavior at Work 13th Edition. New Delhi: Mcgraw Hill Company

Dinas Koperasi Usaha Mikro dan Menengah Provinsi Jawa Timur. (2014). Rencana Strategi tahun 2009 sampai 20014. Pemerintah Provinsi Jawa Timur.

Dinas Koperasi Usaha Mikro Kecil dan Menengah Provinsi Jawa Timur. (2015). Rencana Strategi Tahun 2014 samapai 2019. Pemerintah Provinsi Jawa Timur.

Fred Luthans, (2006), Perilaku Organisasi. Edisi Sepuluh, PT. Andi: Yogyakarta.

Gibson, Vancevich, Donell, (1998). Organisasi dan Manajemen, Edisi Keempat, Erlangga, Jakarta.

Gomes, Faustino Cardoso. (2003). Manajemen Sumber Daya Manusia. Yogjakarta: Andi Offset.

Hamalik, O. (2009). Psikologi Belajar Dan Mengajar . Bandung : Sinar Baru Algesindo.

Hendar, \& Kusnadi (2005). Ekonomi Koperasi (Untuk Perguruan Tinggi). Jakarta : Fakultas Ekonomi Univertsitas Indonesia. FEUI.

Herzberg, F. (1966). Work and The Nature of Man. New York : Work Publishing Co. Edition: Print book. English View all editions and formats

Hudiyanto. (2002). Sistem Koperasi, Ideologi Dan Pengelolaan. Yogyakarta : UI Press.

Hanel, A. (2002). Organisasi Koperasi. Jogjakarta : Graha Ilmu.

http://sbwmalang.com/sejarah-singkat

Junusi, R. E. (2009). Analisis Pertispasi Komitmen dan Kemampuan Berinovasi Serta Pengaruhnya Terhadap Kinerja Koperasi 
Pondok Pesantren Conference Proceedsing, Annual International Conference On Islamic Stuidies (AICIS XII).

Martoyo, Susilo. (2000). Manajemen Sumber Daya Manusia. Yogyakarta: BPFE.

Mahmudi. (2010). Manajemen Kinerja Sektor Publik.UPP STIM YKPN : Yogyakarta.

Marwansyah dan Mukaram (2000), Manajemen Sumber Daya Manusia, Bandung, Politeknik Bandung Press.

Mathis. L. Robert dan Jackson. H. John. (2001).Manajemen SumberDaya Manusia. Bukukedua. Jakarta

Mondy R Wayne. (2008). Manajemen Sumber Daya Manusia. Jakarta: Erlangga

Muryani, (2018). Peran Pemerintah, OCB, dan Motivasi Kerja, Terhadap Kinerja Koperasi Wanita Melalui Partisipasi Anggota Di Kabupaten Gersik. Desertasi, Uniersitas Merdeka Malang.

Purnawaty (2017). Pengaruh Motivasi Berkoperasi Dan Pelayanan Koperasi Terhadap partisipasi Anggota Koperasi Unit Desa (Kud) Marga Jaya Petaling Muaro Jambi. Artikel. Fakultas Keguruan Dan Ilmu Pendidikanuniversitas Jambi

Prihatini. (20012). Proceeding For Call Paper. Pekan Ilmiah DosenFEB-UKSW, (p.74).

Prihatini. (2012). Pengaruh Motivasi Pengurus dan AnggotaTerhadap KinerjaKoperasi Studi Kasus Koperasi Mahasiswa. Jakarta : PERBANAS.

Robbins SP, dan Judge. (2008) . Perilaku Organisasi Buku 2. Hal 256Jakarta : Salemba Empat

Ropke, J. (2003). Ekonomi Koperasi Teori dan Manajemen. Jakarta : Salemba Empat.

Ratnawati, (2015). Mengelola Sumber Daya Manusia Pada Koperasi Wanita (penilaian Kinerja Kopwan Berdasarkan Aspek Organisasi). Fakultas Ekonomi dan Bisnis, Universitas Wisnuwardana Malang.

Rusyana et al (2016). Pengaruh Partisipasi , Komitmen Dan Kemampuan Inovasi Anggota Terhadap Arah Pengembangan Koperasi. Journal of Management.Vol.2 No.2.

Swasto, Bambang. (2011) .Manajemen Sumber Daya Manusia. Malang : UB Press.

Setyadi, (2018). Pengaruh praktek Pengelolaan Sumber Daya Manusia, Kemmapuan Inovasi dan Kepemimpinan Transformasional Terhadap Kinerja Melalui Inovasi Organisasi Pada Perusahaan Manufaktur di Jawa Timur. Desertasi, Universitas Merdeka Malang.
Sinambela, Lijan Poltak. (2012). Kinerja Pegawai. Graha Ilmu: Yogyakarta.

Simamora, Henry. (2006). Manajemen Sumberdaya Manusia. Yogyakarta: Sekolah Tinggi Ilmu Ekonomi YKPN.

Uno, H. (2012). Teori Motivasi dan Pengukurannya. Jakarta : Bumi Aksara.

Wukir . (2013). Manajemen Sumber Daya Manusia Dalam Organisai Sekolah. Yogyakarta : Multi Presindo.

\section{Profil Penulis}

1. Choirul Insyiah, S.E., M.M, Keilmuan Manajemen, Universitas Merdeka (UNMER) Malang. J1. Terusan Dieng No. 62-64 Klojen, Pisang Candi, Kec. Sukun, Kota Malang Jawa Timur - 65146 Email : choirul_insyiah@yahoo.co.id 